九州大学学術情報リポジトリ

Kyushu University Institutional Repository

Endomychidae from Korea (Insecta, Coleoptera)

Chujo, Michitaka

Chujo, Michio

Lee, Chang Eon

https://doi.org/10.5109/2566

出版情報：ESAKIA．33，pp.95-98，1993-03-31. 九州大学農学部附属彦山生物学実験所 バージョン：

権利関係 : 


\title{
Endomychidae from Korea (Insecta, Coleoptera) ${ }^{1,2)}$
}

\author{
Michitaka CHO̊Jó \\ Hikosan Biological Laboratory, Faculty of Agriculture, Kyushu \\ University, Hikosan, Japan 824-07 \\ Michio CHÛ́ô \\ Kamata 1-6-16-505, Ohta-ku, Tokyo, Japan 144 \\ and \\ Chang Eon LeE \\ Department of Biology, College of Natural Sciences, Kyungpook \\ National University, Taegu, 702-701 Korea
}

\begin{abstract}
Until recent time only one endomychid species, Lycoperdina mandarinea Gerstacker was recorded by G. S. Lafer in 1992 from Korea. Following two species are newly added to the Korean fauna of Endomychidae. One is Cymbachus koreanus sp. nov. and the other is Endomychus nigropiceus (Gorham) so far known from Japan.
\end{abstract}

\section{EUMORPHINAE}

\section{Cymbachus koreanus sp. nov.}

Black to dark umber colored, pronotum very weakly and elytra rather strongly convex, antennae and tibiae slender, long. Elytra each with four yellow small markings, two of them subbasal and another two subapical in position.

Head nearly flat, very weakly convex above sockets of antennae, very sparsely punctate, every puncture with short, fine and depressed hair, clypeal suture not grooved but very feebly ridged, clypeus trapezoidally produced, gently convex medially, apical margin rounded. Eyes rather large,

1) Results from the Korea-Japan Co-operative Science Program on "The Evolution and Biogeography of the Insects in the East Asia”. No. 15.

2) Contribution from the Hikosan Biological Laboratory, Faculty of Agriculture, Kyushu University, Hikosan (Ser. 4, No. 7). 
oblique, very finely facetted. Mandibles with apex very sharply pointed and with an internal tooth. Maxillary palpi with terminal joint tapering, oblique at apex. Antennae with basal segment clavate, thick, 2nd to 8th segments more or less cylindrical, terminal 3 segments depressed and making loose club, relative length of each segment (base to apex) $8: 4: 14: 7: 7: 6: 6: 5: 11: 8: 9$. Pronotum very weakly convex, sparsely and strongly punctate, wholly marginate, hind margin bisinuate, with especial two foveae close to hind margin, hind corners angulate; side margins roundly warped outwards, roudly narrowed forwards; front comer strongly projected, but not pointed; front margin very deeply sinuate, with a prominent stridulatory membrance in front part. Prostemum with surface nearly smooth, very sparsely pubescent, prosternal process $\mathrm{V}$-shaped at apical end, not project posteriorly beyond intercoxal cavity. Scutellum nearly triangular, each side very feebly warped outwards and angle not pointed, very feebly aciculate.

Elytra rather strongly convex, densely with strong punctures, strongly and roundly warped outwardly, narrowly marginate from shoulder to apex as seen Fig. 1-A, each with four characteristic yellow patches. Mesostemum with raised up front margin. Metasternum sparsely

punctate, very strongly marginate between middle coxal cavities. Elytral epipleuron very wide at basal part, and strongly narrowed towards apex. Visible abdominal sternites very densely punctatc, with basal segment very wide. Tibiae rather slender, gradually thickened towards apex, middle tibiae with short spur at inside of subapical part in male, but simple in female. Tarsi with 2nd segment widely flabellate, 3rd tiny and mistakable to basal part of 4th one.

Length: $7.5-7.9 \mathrm{~mm}$. Width: $5.1-5.5 \mathrm{~mm}$.

Holotype: male(preserved in the collection of C. E. Lee, Kyungpook Natio. Univ.), Dooryu Dong, Joochun Meon, Samchung Gun, Gyeongsang Nam Do, Korea, 25. ix. 1991, M. T. Chûjô leg. Paratopotypcs: 8 males \& 2 females, same collection data with holotypc. Paratypes: 2 males \& female, Naelycon Ri, Samnae Myeon, Cheonla-buk Do, Korea, 13. vii. 1991, M. T. Chûjô leg.; male, Samjeong Ri, Macheon Myeon, Cheonla-buk Do, Korea, 14. vii. 1991, M. T. Chûjô leg.; male \& 2 females, Jeonglyeon Chi, Samnae Myeon, Cheonla-buk Do, Korea, 16. vii. 1991, M. T. Chûjô leg.; 3 males, Dooryu Dong, Joochun Meon, Samchung Gun, Gyeongsang Nam Do, Korea, 25. ix. 1991, K. Morimoto leg.; 2 females, Jeonglyeong Chi, SamNae Meon, Namweon Gun, Jeongra-buk Do, Korea, 28. ix. 1991, M. T. Chûjô leg.

Distribution: Korea (South part).

This new species is related to Cymbachus quadrimaculatus (Pic, 1927) from Tonkin and Fukien, but is easily distinguished from the latter by the following characters: pronotum more deeply sinuate at front margin, side margins more roundly warped outwards, and shoulder not convex.

\section{ENDOMYCHINAE}

\section{Endomychus nigropiceus (Cm-ham)}

Cyanauges nigropiceus Gorham, 1887, Proc.Zool. Soc. London: 651 (Japan: Honshu).

Spec. exam.: 1 ex., Samjeong Ri, Macheon Myeon, Chconla-buk Do, Korea, 14. vii. 1991, M. T. Chûjôleg.

Gen. distr.: Korea (South part) \& Japan (Hokkaido, Honshu, Shikoku, Kyushu \& Tsushima Is.). 


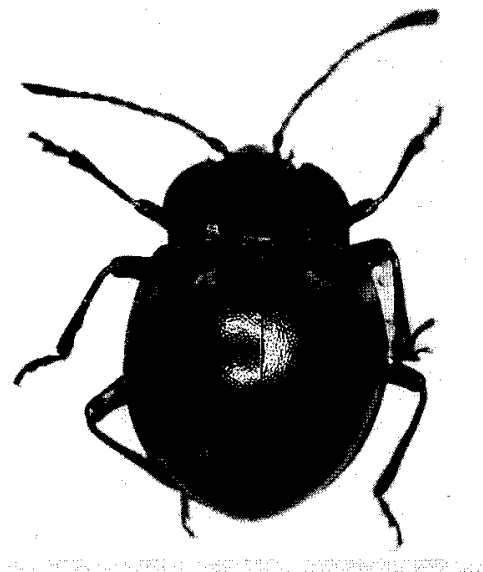

A

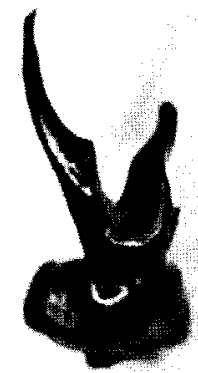

B

Fig. 1. Cymbachus koreanus sp. nov. A: Dorsal aspect; B: male genitalia, obliquo-dorsal aspect.

\section{ACKNOWLEDGEMENT}

WC arc very grateful to Director general Jae Myeong Jo, Forest Research Institute, Korea, and Director Seung Kul Park, Chung-bu Forest Experiment Station, Korea for giving us the various help on to our collecting trip in Korea. And also, we express our cordial thanks to Prof. Dr. Chan Young Lee, Kangweon National University, Korea and Dr. Jong Kuk Kim, Forest Research Institute, Korea, for their kind help for our collecting trip. WC wish to express our appreciation to Prof. Dr. K. Morimoto, Entomological Laboratory of Kyushu University for his continual kind and valuable guidance. And also wC are thankful to Assoc. Prof. Dr. 0. Tadauchi and Assist. Prof. Dr. S. Nomura of Entomological Laboratory of Kyushu University for their various cooperation for this work. 


\section{SELECTED REFERENCE}

Arrow, G. J., 1925. Endomychidae. Fauna of British India: 268-297.

Gorham, H. S., 1887. Revision of the Japanese species of the Coleopterous family Endomychidae. Proc. Zool. Soc. London: 264-653, PI. 53.

Lafer, G. S., 1992. Endomychidae, In Ler, P. A. ed., Keys to the identification of the insects of the Russian Far East., vol. 4, Coleoptera, part 2: 331, P1. 152, Fig. 3. (in Russian)

Ohta, Y., 1931. Beitrag zur Kenntnis der Endomychiden Japans. J.Fac. Agr., Hokkaido Univ., 30 (4): 205-242, Taf. 3.

Strohecker, H. F., 1953. Col., Fam. Endomychidae. Genera Ins., (210): 1-138, 5 pls. 